\title{
HAK IMUNITAS ADVOKAT BERDASARKAN PASAL 16 UNDANG-UNDANG NOMOR 18 TAHUN 2003 TENTANG ADVOKAT JO PUTUSAN MAHKAMAH KONSTITUSI NOMOR 26/PUU-XI/2013, TANGGAL 14 MEI 2014
}

\author{
Oleh : Imron
}

Dosen Fakultas Ekonomi Universitas 17 Agustus 1945 Samarinda

\begin{abstract}
Advocates are people who work in providing legal services, both inside and outside the court, advocates are also a noble or honorable profession, advocates have a role that is no less important than other law enforcers and has the same position as a law enforcer so that it is natural for lawyers to have the right of immunity, namely the right of immunity to the work of his profession.

Advocates in carrying out their profession, cannot be prosecuted both civil and criminal in carrying out their professional duties in good faith for the benefit of the client's defense outside or in court, but in practice there are many cases involving advocates when carrying out their profession in the field up to the verdict until the verdict criminal.

The problem raised in this paper is whether the lawyer is immune to the law with the existence of an advocate's immunity rights and how the legal protection of the advocate's immunity rights in carrying out his profession. This type of research is normative juridical research, library research with the problem approach used in writing this thesis is the statute approach.

With the enactment of laws and regulations governing the rights of advocates of immunity, that advocates are not immune from the law but because the tasks or work done by advocates constitute the work or noble profession, then he is given special authority, namely the right of immunity or the right to immunity in law carrying out his professional duties.
\end{abstract}

\section{Keywords : impunity in good faith.}




\section{PENDAHULIAN}

\section{A. Latar Belakang}

Seiring kemajuan jaman, tingginya kebutuhan akan jasa advokat di Indonesia tidak disangkal lagi, karena Indonesia mengalami perubahan yang mendasar dibidang hukum, sebelumnya hukum dianggap sebagai pelengkap dalam kehidupan bermasyarakat namun belakangan dijadikan harapan untuk menuntaskan berbagai masalah sosial, hal ini dapat dilihat dari kenyataan bahwa hampir semua urusan dalam kehidupan warga negara dapat dipastikan menyentuh sisi hukum yang kebanyakan membutuhkan jasa advokat, yang dimaksud dengan jasa advokat adalah jasa hukum yang berupa pemberian konsultasi hukum, bantuan hukum, menjalankan kuasa, mewakili, mendampingi, membela, dan melakukan tindakan-tindakan hukum untuk kepentingan klien.

"Dalam usaha mewujudkan Prinsip-prinsip Negara Hukum dalam kehidupan bermasyarakat dan bernegara, peran dan fungsi Advokat sebagai profesi yang bebas, mandiri dan bertanggung jawab merupakan hal yang penting, disamping lembaga peradilan dan instansi penegak hukum, seperti Kepolisian dan Kejaksaan. melalui jasa hukum yang diberikan, Advokat menjalankan tugas dan profesinya demi tegaknya keadilan berdasarkan hukum untuk kepentingan masyarakat dalam menyadari hak-hak yang fundamental mereka didepan hukum. Advokat sebagai salah satu unsur sistem peradilan merupakan salah satu pilar dalam menegakkan Supremasi hukum dan hak asasi manusia."1

Berdasarkan ketentuan Undang-Undang Nomor 18 Tahun 2003 tentang Advokad, Advokat merupakan penegak hukum yang berdasarkan pada doktrin maupun tradisi, advokat bersama-sama dengan polisi, jaksa dan hakim, atau penegak hukum lainnya. Karena advokat sebagai kuasa dari masyarakat yang membutuhkan bantuan hukum, maka turut serta dalam proses penegakkan hukum

Profesi Advokat merupakan profesi yang relatif tua usianya, bahkan jauh sebelum kemerdekaan Indonesia, profesi advokat sudah dikenal dalam masyarakat Indonesia. Pada Tahun 1947 telah diperkenalkan suatu peraturan yang mengatur profesi advokat. Peraturan yang dikenal dengan nama, Reglement op de Rechterlijke organisatie en het Beleid der justitie in Indonesia (S. 1847 No. 23 yo S.1848 No. 57) dengan segala perubahan dan penambahannya. Artinya telah ada aturanaturan yang berkaitan dengan advokat sejak Tahun 1947.

\footnotetext{
${ }^{1}$ Andika Wijaya dan Wida Peace Ananta, 2019, Ujian Profesi Advokat, Cet. IV, Penerbit PT Grasindo, Jakarta, hal. 1.
} 
"Advokat sebagai salah satu pilar penegakkan hukum bersamasama dengan jaksa, polisi, dan hakim berperan penting dalam proses pemeriksaan perkara. Maka profesi ini sering disebut sebagai offcium nobile, yakni jabatan yang mulia. Karena dalam menjalankan tugasnya advokat dibekali kode etik serta memiliki kewajiban untuk memperjuangkan hak kliennya sebagai salah satu peran dalam proses penegakkan hukum, dalam sistem peradilan pidana, advokat merupakan satu-satunya penegak hukum yang berkedudukan di luar lembaga pemerintahan, artinya advokat bekerja secara independent tanpa ada interfensi. Meskipun bukan merupakan bagian dari lembaga pemerintahan advokat memiliki kedudukan yang sama dengan penegak hukum lain seperti Jaksa, Hakim, dan Polisi, hal ini telah diatur dalam UndangUndang No. 18 Tahun 2003 tentang Advokat, yang berbunyi : Advokat bersetatus sebagai penegak hukum, bebas dan mandiri yang dijamin oleh hukum dan peraturan perundang-undangan". ${ }^{2}$

Sebagai pilar penegak hukum, sudah seharusnya kedudukan advokad sejajar dengan penegak hukum lainnya, meskipun advokat bukan merupakan bagian dari lembaga pemerintahan, dalam hal ini erat kaitannya dengan hak yang dimiliki para penegak hukum, yakni hak imunitas atau kekebalan, dengan begitu aparat penegak hukum akan bekerja dengan maksimal tanpa adanya tindakan Berdasarkan Pasal 16 Undang-Undang Nomor. 18 Tahun 2003 tentang Advokat dan dengan Putusan Mahkamah Konstitusi Nomor 26/PUU-XI/2013 Tanggal 14 Mei 2014 terkait pengujian pasal 16 Undang-Undang Nomor 18 Tahun 2003 Tentang Advokad, yang berbunyi: Advokat tidak dapat dituntut baik secara perdata maupun pidana dalam menjalankan tugas profesinya dengan iktikad baik untuk kepentingan pembelaan klien didalam maupun diluar sidang pengadilan.

Undang-undang Advokat sebagai sumber rujukan dan jaminan kepastian dalam menjalankan profesinya akan tetapi meskipun telah ada peraturan perundang-undangan yang mengatur tentang hak imunitas bagi advokat, namun apabila melihat yang terjadi saat ini, banyak sekali advokat yang dilaporkan ke pihak yang berwajib atas kelalaian ataupun kesalahan, penyalahgunaan wewenangnya dalam menjalankan tugasprofesinya.

"Seperti yang telah diberitakan oleh Liputan6.com, jakarta bahwa, ada beberapa pengecara atau advokad yang terkena kasus pidana sepertidari catatan ICW (Indonesia Coruuption Watch), ada tiga jenis kasus dalam Undang-Undang Tipikor yang melibatkan para advokat.

${ }^{2}$ https://www.google.com/search?client=firefox-b-d\&q=skripsi+hak+imunitas+advokat.

Diakses Hari Saptu, 15 februari 2020, Pukul 8:20 Wita. 
advokat terkena pasal penyuapan, dua advokat disangkakan pasal pemberian keterangan palsu, sementara empat advokat dianggap menghalang-halangi penyidikan kasus korupsi". ${ }^{3}$

Kasus-kasus diatas menarik untuk dikaji dan dibahas lebih mendalam berkaitan dengan hak imunitas yang dimiliki advokat, karena dalam prakteknya perihal hak imunitas yang dimiliki advokat sering kali tidak dipahami oleh penegak hukum lain. Sehingga berprofesi sebagai Advokat dapat terjerat hukum dalam menjalankan profesinya. Hal-hal tersebut menarik untuk dibahas jika menghubungkannya dengan ketentuan Pasal 16 Undang-Undang Nomor 18 Tahun 2003 Tentang Advokat, yang menyatakan bahwa seorang advokat tidak dapat dituntut baik secara perdata maupun secara pidana dalam menjalankan tugas profesinya,dari uraian-uraian tersebut di atas penulis akan mengadakan suatu penelitian dengan memberikan sebuah judul yaitu "Hak Imunitas Advokat Berdasarkan Pasal 16 Undang-Undang Nomor 18 Tahun 2003 Tentang Advokat Jo Putusan Mahkamah Konstitusi Nomor 26/PUUXI/2013 Tanggal 14 Mei 2014."

\section{B. Rumusan Masalah}

Berdasarkan uraian latar belakang permasalahan di atas, maka rumusan permasalahan dalam penulisan ini adalah :

1. Apakah advokat kebal hukum dengan adanya hak imunitas advokat menurut Pasal 16 Undang-Undang Nomor 18 Tahun 2003 Tentang Advokat Jo Putusan Mahkamah Konstitusi Nomor 26/PUU-XI/2013 Tanggal 14 Mei 2014 ?

2. Bagaimana perlindungan hukum terhadap hak imunitas Advokat dalam menjalankan profesinya menurut Pasal 16 Undang-Undang Nomor 18 Tahun 2003 Tentang Advokat Jo Putusan Mahkamah Konstitusi Nomor 26/PUU-XI/2013 Tanggal 14 Mei 2014 ?

\section{KERANGKA DASAR TEORI}

\section{A. Asas Legalitas (Asas Yang Tertulis)}

Asas legalitas merupakan asas yang menjamin kepastian hukum bagi setiap orang atau subyek hukum, sebagaimana dikutip dalam Buku Pengantar Hukum Indonesia yang dalam bukunya juga membahas mengenai asas legalitas.

\footnotetext{
${ }^{3}$ https://www.jawapos.com/nasional/hukum-kriminal/14/01/2018/icw-selain-fredrichsudah -ada-22-advokat-yang-terjerat-kasus-hukum/ Diakses Hari Saptu, 15 februari 2020 Pukul 8:20 Wita.
} 
"Asas yang tertulis atau asas Legalitas tercantum dalam Pasal 1 ayat (1) KUHP yang berbunyi: Tiada suatu peristiwa dapat dipidana, melainkan atas kekuatan, ketentuan-ketentuan Undang-Undang, yang berlaku terdahulu dari peristiwa itu, Pasal 1 ayat (1), karena tercantum sebagai ketentuan undang-undang maka disebut asas yang tertulis, dalam bahasa latinya asas ini disebut Asas Nullum Delictum, Nula Poena Sine Prae Via Lege Poenali atau disingkat Asas Nullum Delictum artinya asas ini adalah: bahwa suatu perbuatan tidak dapat dipidana selain atas kekuatan peraturan undang-undang pidana yang terdahulu diadakan sebelum perbuatan itu dilakukan. Asas ini merupakan jaminan untuk keamanan hukum dan melindungi orang-orang terhadap perbuatan sewenang-wenang dari hakim, maka sebagai akibat dari asas legalitas ini ialah: perbuatan-perbuatan yang diancam dengan pidana harus lebih dahulu dinyatakan didalam peraturan perundang-undangan (Pasal 14 ayat (2) UUDS 1950), dalam menentukan adanya perbuatan pidana, tidak mungkin digunakan Analogie (kias), aturan-aturan undang-undang pidana tidak mungkin berlaku surut. Analogi adalah: suatu penafsiran undangundang sedemikian rupa sehingga suatu peristiwa hukum yang sebenarnya atas peristiwa tersebut belum ada ketentuan undang-undangnya, maka berdasarkan penafsiran analogi, peristiwa hukum itu akhirnya dapat juga dikenakan ketentuan undang-undang yang tidak dapat mengatur peristiwa tersebut". 4

\section{B. Asas Praduga Tak Bersalah}

Pengertian asas praduga tak bersalah tersebut membawa makna bahwa dalam proses pelaksanaan acara pidana, tersangka atau terdakwa wajib diperlakukan sebagai orang yang tidak bersalah, sehingga petugas penyidik, penuntut umum, dan hakim harus memperhatikan hak-hak yang ada padanya terlebih mengenai hak asasinya benar-benar harus diperhatikan dan dilindungi.

Asas praduga tak bersalah diatur pada Kitab Undang-Undang Hukum Acara Pidana (KUHAP), dan Undang-Undang Nomor 48 Tahun 2009 mengenai kekuasaan kehakiman. Di KUHAP, asas ini diterangkan pada penjelasan umum Kitab Undang-Undang Hukum Acara Pidana (KUHAP) pada butir ke 3 huruf c dengan bunyi sebagai berikut: "setiap orang yang disangka, di tangkap, di tahan, dituntut atau dihadapkan di muka sidang, wajib dianggap tidak bersalah sampai adanya putusan

\footnotetext{
${ }^{4}$ Abdul Munif, 2013, Pengantar Hukum Indonesi, Cet 2, Penerbit Cakrawala Media, Yogyakarta, Hal 107.
} 
pengadilan yang menyatakan kesalahannya dan telah memperoleh kekuatan hukum tetap",

\section{Asas Persamaan di Hadapan Hukum (Eqealiti Before The Law Principle)}

Asas Persamaan di Hadapan Hukum (Eqealiti Before The Law Principle), merupakan salah satu asas yang utama dalam Dekalrasi Universal HAM dan dianut pula dalam UUD 1945, yang mengandung arti bahwa, semua warga harus mendapat perlindungan yang sama dalam hukum, tidak boleh ada diskriminasi dalam perlindungan hukum.

"Kata kunci perlindungan, maka yang dituju adalah perintah pada negara atau pemerintah untuk memberi perlindungan hukum yang sama adilnya, kepadad warganya dan dalam sebuah negara dengan masyarakat majemuk atau bersifat multi-kultural seperti Indonesia, ini mengandung makna perlindungan terhadap kelompok minoritas (terhadap kemungkinan ketidak adilan dari kelompok manyoritas), mencegah adanya diskriminasi dalam perlindungan dan rasa aman kelompok minoritas. Diskriminasi yang dilarang adalah yang merugikan kelompok tertentu. Namun kalau dipergunakan kata kunci Perlakuan, maka penafsiran yang berkembang didalam masyarakat indonesia adalah perintah kepada negara atau pemerintah untuk tidak membedakan didalam perlakuan hukum antara warganya, dan dalam masyarakat yang terstruktur dalam kelas, maka ini mengandung makna jangan memberi perlakuan yang istimewa kepada anggota kelas tertentu". 6

\section{Undang-Undang Dasar 1945}

Undang-Undang Dasar 1945 merupakan sumber hukum tertinggi dan fundamental sifatnya karena merupkan sumber legitimasi atau landasan torisasi bentuk-bentuk hukum atau peraturan perundangundangan lainnya. Sesuai dengan prinsip hukum yang berlaku secara universal, segala peraturan perundang-undangan yang tingkatannya berada dibawah Undang-Undang Dasar tidak mempunyai kekuatan hukum mengikat dan tidak dapat diberlakukan apabila bertentangan dengan Undang-Undang Dasar.

\footnotetext{
${ }^{5}$ Undang-Undang Nomor 8 Tahun 1981 Tentang Kitab Undang-Undang Hukum Acara Pidana, (KUHAP).

${ }^{6} \mathrm{https}$ ///www_hukumonline.com/berita/baca/lt540d7c056fc44/hak-imunitas-dan-asas -persamaan-kedudukan-di-hadapan-hukum-dalam-uu-md3-broleh--prof-mardjonoreksodiputro--sh--ma/Diakses Hari Kamis 26 Maret 2020, Pukul 13:01 Wita.
} 
Undang-Undang Dasar 1945 menegaskan dalam Pasal 1 ayat (3), Negara Indonesia adalah Negara Hukum,

Pasal 3

(1) Setiap orang dilahirkan bebas dengan harkat dan martabat manusia yang sama dan sederajat serta dikaruniai akal dan hati murni untuk hidup bermasyarakat, berbangsa, dan bernegara dalam semangat persaudaraan.

(2) Setiap orang berhak atas pengakuan, jaminan, perlindungan dan perlakuan hukum yang adil serta mendapat kepastian hukum dan perlakuan yang sama di depan hukum.

(3) Setiap orang berhak atas perlindungan hak asasi manusia dan kebebasan dasar manusia, tanpa diskriminasi.

\section{E. Pengertian Advokat}

Asal kata Advokat, apabila didasarkan pada kamus LatinIndonesia, dapat ditelusuri dari bahasa latin, yaitu advocatus, yang berarti antara lain yang membantu seseorang dalam perkara, saksi yang meringankan, sedangkan menurut Black`s Law Dictionary, kata advokat juga berasal dari kata Latin yaitu advocare suatu kata kerja yang berarti to defend, to call one's aid, to vouch to warant. Sebagai kata benda (noun), kata tersebut berarti: seseorang yang membantu, mempertahankan, membela orang lain, seseoarng yang memberikan nasehat dan bantuan hukum, serta berbicara untuk orang lain dihadapan pengadilan.

Berdasarkan uraian diatas, pengertian advokat memperoleh penekanan pada pekerjaan yang berkaitan dengan pengadilan. Sedangkan dalam Undang Undang Nomor 18 Tahun 2003 tentang Advokat, sudah ditegaskan bahwa advokat adalah orang yang melakukan pekerjaannya baik didalam maupun diluar pengadilan.

\section{F. Pengertian Profesi Advokat}

Profesi advokat secara umum pekerjaan sementara dalam arti khusus yaitu pekerjaan bidang tertentu mengutamakan kemampuan fisik dan intelektual, bersifat tetap dengan tujuan memperoleh pendapatan atau pengahasilan. Profesi juga dapat dirumuskan sebagai pekerjaan tetap dibidang tertentu berdasarkan keahlian khusus yang dilakukan secara bertanggung jawab dengan tujuan memperoleh penghasilan. profesi dibutuhkan lima hal, yaitu pengtahuan, penerapan keahlian, tanggung jawab sosial, self control, dan pengakuan dari masyarakat. Profesi menuntut pemenuhan nilai moral dari pengembannya. Nilai moral merupakan kekuatan yang mengarahkan dan mendasari perbuatan luhur.

"Secara tradisional, ada empat jenis profesi, yaitu kedokteran, hukum, pendidikan, dan keagamaan. Sesuasi dengan 
perkembangan jaman, maka jenis-jenis profesi semakin bertambah, seperti profesi akuntan dan tehknik. Ciri khas yang membedakan profesi hukum dengan profesi lainnya adalah profesi hukum yang bersentuhan langsung dengan kepentingan manusia atau orang lain yang disebut dengan klien. Mengenai profesi hukum yang dapat memberikan pelayanan bantuan jasa hukum kepada masyarakat, menurut Kansil, dapat dikualfikasikan menjadi lima jenis. Dewasa ini dikenal dengan beberapa subyek hukum berpredikat profesi hukum, yaitu:

a. Hakim;

b. Penasehat Hukum (advokat/pengecara);

c. Notaris;

d. Jaksa;

e. Polisi, yang masing-masing dilengkapi dengan etika profesi hukum, agar dapat melaksanakan fungsi dan kegiatannya dengan sebaikbaiknya".?

Berdasarkan pendapat diatas, maka di Indonesia mengenal lima jenis profesi hukum dan dalam melaksanakan fungsi serta kegitannya dilengkapi dengan etika profesi hukum yang disebut dengan kode etik profesi.

\section{G. Profesi Yang Mulia (Officium Nobile)}

Profesi advokat dinamai pula dengan Officium Nobile, secara harfiah diterjemahkan sebagai profesi mulia. Kata Officium berarti suatu aktifitas untuk pemberian pelayanan, sementara Nobile berarti mulia atau bermartabat tinggi. Kata Nobile Officium, mengandung arti adanya kewajiban yang mulia atau yang terpandang dalam melaksanakan pekerjaan mereka. Serupa dengan ungkapan yang kita kenal Noblesse Oblige, yaitu kewajiban prilaku yang terhormat (Honorable), murah hati (Generous), dan bertanggung jawab (Responsible), yang dimiliki oleh mereka yang ingin dimuliakan, hal ini berarti bahwa seorang anggota profesi advokat tidak hanya harus berprilaku jujur dan bermoral tinggi, tetapi harus juga mendapat kepercayaan publik.

"Sebagai profesi mulia, pengemban profesi advokat sebagai, profesi hukum, dituntut melaksanakan profesi hukumnya dengan mendasarkan diri pada nila-nilai moralitas umum (Common Morality) seperti:

1. Nilai-nilai kemanusiaan (Humanity) dalam arti penghormatan pada martabat kemanusiaan;

\footnotetext{
${ }^{7}$ V. Yahman dan Nurtin Tarigan, 2019, Peran Advokat Dalam Sistem Hukum Nasional, Cet I, Penerbit Prenadamedia Group, jakarta, Hal 47.
} 
2. Nilai keadilan (Justice) dalam arti dorongan untuk selalu memberikan kepada orang apa yang menjadi haknya;

3. Nilai kepatutan atau kewajaran (Reasonableness) dalam arti bahwa upaya mewujudkan ketertiban dan keadilan didalam masyarakat;

4. Nilai kejujuran (Honesty) dalam arti adanya dorongan kuat untuk memilihara kejujuran dan menghindari diri dari perbuatan curang;

5. Kesadaran untuk selalu menghormati dan menjaga integritas dan kehormatan profesinya;

6. Nilai pelayanan kepentingan publik (To Serve Public Interest) dalam arti bahwa didalam pengembangan profesi hukum telah Inherent semangat keberpihakan pada hak-hak dan kepuasan masyarakat pencari keadilan yang merupakan konsekuensi langsung dari dipegang teguhnya nilai-nilai keadilan, kejujuran, dan kredibilitas profesinya". ${ }^{8}$

Penyebutan profesi mulia atau Officium Nobile kepada profesi advokat didasarkan pada alasan bahwa faktor menguasai ilmu pengetahuan hukum bukan merupakan modal utama bagi seorang advokat namun juga harus memiliki nilai kejujuran dan panggilan nurani.

\section{H. Pengertian Hak Imunitas Advokat}

Hak imunitas advokat merupakan hak atas kekebalan advokat dalam menjalankan profesinya,

"Istilah hak imunitas tidak ditemukan dalam Undang-Undang Adokat tetapi, untuk memahami pengertian hak imunitas, kita dapat memulainya dari pengertian Hak. Hak dapat didefinisikan sebagai alokasi kekuasaan kepada seseorang secara terukur dalam arti keluasan dan kedalamannya, dari asal usul kata, istilah imunitas dapat ditelusuri ke Immunis, kata latin yang antara lain berarti pembebasan dari kewajiban umum, kebebasan/pembebasan pajak/kewajiban militer/pekerjaan rodi, hak istimewa.

Berdasarkan pengertian tersebut, dapat dikatakan bahwa hak imunitas adalah kebebasan advokat untuk melakukan atau tidak melakukan setiap tindakan atau mengeluarkan atau tidak mengeluarkan pendapat, keterangan atau dokumen kepada siapapun dalam melaksanakan tugasnya sehingga advokat tersebut tidak dapat dihukum dalam melaksanakan tugasnya".

Salah satu profesi yang memiliki hak imunitas adalah Advokat. Hak ini diberikan oleh Undang-Undang Nomor 18 Tahun 2003 adalah hak kekebalan hukum atau lebih sering dikenal dengan istilah hak imunitas,dalam Undang-Undang Nomor 18 Tahun 2003 tersebut

${ }^{8}$ Ibid, Hal 51

${ }^{9}$ V. Harlen Sinaga, 2011, Dasar-dasar Profesi Advokat, Cet I, Penerbit Erlangga, Jakarta. Hal, 120 dan 121 
dijelaskan lebih lanjut bahwa advokat bebas dalam melaksanakan tugas profesinya termasuk pula bebas untuk mengeluarkan pendapat atau pernyataan dalam membela perkara yang menjadi tanggung jawabnya dengan tetap berpedoman pada Kode Etik Profesi Advokat dan peraturan perundang-undangan. Adapun yang dimaksud bebas dalam kaitannya dengan melaksanakan tugas profesi advokat tersebut adalah tanpa adanya tekanan dan ancaman yang akan menimbulkan rasa takut atau adanya perlakuan yang merendahkan harkat dan martabat profesi advokat sebagai profesi yang mulia (Officium Nobile).

Advokat dibekali dengan hak imunitas sebagaimana yang diatur dalam Undang-Undang Nomor 18 Tahun 2003 yang menyebutkan bahwa seorang advokat untuk tidak dapat dituntut baik secara perdata maupun pidana dalam menjalankan tugas profesinya dengan itikad baik untuk kepentingan pembelaan klien di dalam maupun di luar sidang pengadilan, namun hak imunitas Advokat bukannya tanpa batasan, sebagaimana disebutkan dalam tersebut bahwa hak imunitas berlaku selama Advokat melakukan tugas profesinya dengan itikad baik. Itikad baik ini mengacu pada penjelasan Pasal 16 UU Advokat yaitu menjalankan tugas profesi demi tegaknya keadilan berdasarkan hukum untuk membela kepentingan kliennya. Pengertian itikad baik tersebut mensyaratkan dalam membela kepentingan kliennya pun harus tetap berdasarkan aturan hukum. Atau dalam kata lain tidak bertentangan dengan Undang-Undang dan Kode Etik Profesi Advokat.

\section{Undang-Undang Nomor 18 Tahun 2003 Tentang Advokat}

Undang-Undang Nomor 18 Tahun 2003 Tentang Advokat, dengan di sahkannya pada 5 April 2003, profesi advokat telah memiliki undangundang khusus yang mengatur profesinya. Hal positif yang dapat ditarik dari pengaturan undang-undang ini adalah diberikannya kepercayaan kepada profesi advokat untuk mengatur dirinya sendiri secara otonom.Kewenangan-kewenangan vital seperti pendidikan profesi, pengangkatan, sertifikasi, pengawasan dan penindakan terhadap advokat yang dahulu dipegang oleh Mahkamah Agung dan Menteri Kehakiman, telah diserahkan kepada masyarakat advokat sendiri sebagai bentuk pengakuan atas kemandirian profesi advokat.Secara eksplisit undangundang tentang advokat (UU Advokat) juga menyadari pentingnya keberadaan pengawasan eksternal terhadap profesi advokat. Stigma negatif dari masyarakat terhadap profesi advokat yang selama ini dinilai cenderung tertutup, tidak transparan dan memiliki semangat Corps yang berlebihan berusaha untuk diperbaiki dengan dilibatkannya pihak eksternal yang berasal dari kalangan akademisi hukum dan tokoh masyarakat dalam pelaksanaan fungsi pengawasan dan fungsi mengadili 
terhadap advokat yang diduga melakukan pelanggaran kode etik dan aturan internal profesi lainnya.

\section{J. Putusan Mahkamah Konstitusi Nomor 26/PUU-XI/ 2003 Tanggal 14 Mei 2014.}

Majelis Mahkamah Konstitusi (MK), akhirnya mengabulkan tuntutan sejumlah advokat muda agar memperoleh perlidungan diluar sidang lewat uji materi Pasal 16 Undang-Undang Nomor 18 Tahun 2003 Tentang Advokat. Majelis menyatakan Pasal tersebut Inskonstitusional bersyarat, dalam putusannya Mahkamah Konstitusi menyatakan Pasal 16 UU Advokat harus dimaknai bahwa advokat tidak dapat dituntut secara pidana dan perdata selama menjalankan tugas dan profesinya dengan itikad baik didalam maupun diluar persidangan. Pasal 16 UU Advokat bertentangan dengan UUD 1945 dan tidak memiliki kekuatan hukum yang mengikat sepanjang tidak dimaknai, advokat tidak dapat dituntut baik secara perdata maupun pidana dalam menjalankan tugas profesinya dengan etikad baik, untuk kepentingan pembelaan klien didalam maupun diluar sidang pengadilan, ucap ketua majelis, Hamdan Zoelva, saat membacakan putusaan nomor 26/PUU-XI/2013 Tanggal 14 Mei 2014 digedung MK, Rabu 14 Mei 2013. Sebelumnya tiga advokat muda yaitu Rangga Lukita Desnata, Oktavianus Sihombing, dan Dimas Arya Perdana, mempersoalkan Pasal 16 UU Advokat lantaran hanya memberi perlindungan hukum terhadap advokat didalam persidangan, sementara diluar persidangan tidak jelas perlindungan hukumnya. Padahal kepentingan profesi advokat diluar pengadilan terkait kepentingan kliennya cukup banyak seperti: melakukan mediasi, somasi, pendampingan hingga menggelar konfrensi pers terkait perkara yang ditangani. Para pemohon meminta Mahkamah Konstitusi membatalkan Pasal 16 UU Advokat karena bertentangan dengan Pasal 28D ayat (1), Pasal 28G ayat (1), UUD 1945, atau Pasal itu dinyatakan konstitusional bersyarat sepanjang diartikan advokat tidak dapat dituntut baik secara perdata maupun pidana dalam menjalankan tugas profesinya dengan etikad baik untuk kepentingan pembelaan klien diluar dan didalam sidang pengadilan.

Mahkamah Konstitusi menilai mengacu Pasal 1 angka 1 UU Advokat, tugas dan peran advokat untuk kepentingan klien dapat dilakukan didalam maupun diluar persidangan..

\section{K. Etika Profesi Hukum}

Pengembangan profesi hukum haruslah memiliki keahlian yang berkeilmuan, khususnya dalam bidang hukum, oleh karena itu setiap profesional harus secara mandiri mampu memenuhi kebutuhan warga 
masyarakat yang memerlukan pelayanan dalam bidang hukum, oleh karena itulah didalam melaksanakan profesi terdapat kaidah-kaidah pokok berupa etika profesi yaitu sebagai berikut:

a. Profesi harus dipandang dan dihayati sebagai suatu pelayanan, karena itu maka sifat tanpa pamrih menjadi ciri khas dalam mengembangkan profesi.

b. Pelayanan profesional dalam mendahulukan kepentingan klien mengacu kepada kepentingan atau nilai-nilai luhur sebagai norma kritik yang memotifasi sikap dan tindakan.

c. Pengemban profesi harus selalu beroreantasi pada masyarakat sebagai keseluruhan.

d. Agar persaingan dalam pelayanan berlangsung secara sehat sehingga dapat menjamin mutu dan peningkatan mutu pengemban profesi, maka pengembangan profesi harus bersemangat solidaritas antara sesama rekan seprofesi.

Uraian di atas terlihat betapa eratnya hubungan antara etika dengan profesi hukum, sebab dengan etika inilah para profesional hukum dapat melaksanakan tugas (Pengabdian) profesinya dengan baik untuk menciptakan penghormatan kepada martabat manusia yang pada akhirnya akan melahirkan keadilan ditengah-tengah masyarakat.

\section{Kode Etik Profesi Advokat}

Pengertian atas kata 'Etik’ selalu dikaitkan dengan prinsip-prinsip untuk mengevaluasi sesuatu perbuatan baik atau buruk, benar atau salah yang harus dijadikan pegangan untuk menjaga martabat dan kehormatan profesi advokat, disusun kode etik profesi advokat oleh organisasi advokat. Pada prinsipnya seluruh advokat wajib tunduk dan mematuhi kode etik profesi advokat dan ketentuan tentang dewan kehormatan organisasi advokat. Kode etik profesi advokat tidak boleh bertentangan dengan peraturan perundang-undangan. Pada dasarnya, advokat sebagai profesi terhormat (Officium Nobile) yang dalam menjalankan profesinya berada dibawah perlindungan hukum, undang-undang dan kode etik, memiliki kebebasan yang didasarkan pada kehormatan dan kepribadian advokat yang berpegang teguh pada kemandirian, kejujuran, kerahasiaan, dan keterbukaan . Kode Etik Advokat Indonesia dibuat dan diprakarsai oleh Komite Kerja Advokat Indonesia, yang disahkan dan ditetapkan oleh Ikatan Advokat Indonesia Pada 23 Mei 2002. berdasarkan ketentuan Pasal 33 UU Advokat, Kode etik dan ketentuan tentang Dewan Kehormatan profesi advokat yang telah ditetapkan Pada 23 Mei 2002 dinyatakan mempunyai kekuatan hukum secara mutatis mutandis menurut UU Advokat sampai ada ketentuan baru yang dibuat oleh organisasi advokat 


\section{Peran dan Hak-Hak Advokat dalam KUHAP}

Penjelasan umum Undang-Undang Advokat ditegaskan bahwa Undang-Undang Dasar Negara Republik Indonesia Tahun 1945 menetukan secara tegas bahwa negara Indonesia adalah negara hukum., Undang-Undang Dasar juga menetukan bahwa setiap orang berhak atas pengakuan, jaminan, perlindungan dan kepastian hukum yang adil serta perlakuan yang sama dihadapan hukum, dalam usaha mewujudkan prinsip-prinsip negara hukum dalam kehidupan bermasyarakat dan bernegara, peran dan fungsi advokat sebagai profesi yang bebas, mandiri dan bertanggung jawab merupakan hal yang penting, disamping lembaga peradilan instansi penegakan hukum seperti kepolisian dan kejaksaan. Melalui jasa hukum yang diberikan, advokat menjalankan tugas profesinya demi tegaknya keadilan berdasarkan hukum untuk kepentingan masyarakat pencari keadilan, termasuk usaha memberdayakan masyarakat dalam menyadari hak-hak fundamental mereka dihadapan hukum. Advokat sebagai salah satu unsur sistem peradilan merupakan salah satu pilar dalam menegakkan supermasi hukum dan hak asasi manusia.

"Sebagai komponen sistem peradilan pidana, advokat mengemban tugas dan fungsi penting untuk mewujudkan keadilan dan kebenaran dalam kehidupan berbangsa, bernegara dan bermasyarakat. Adapun peran advokat dalam KUHAP sebelum berlakunya UU Advokat, KUHAP telah mengatur hak-hak tersangka atau terdakwa untuk memperoleh bantuan hukum. Pasal 54 hingga Pasal 57 KUHAP mengatur hak-hak tersangka untuk mendapatkan Penasehat Hukum dan Pasal 69 Pasal 74 KUHAP mengatur mengenai tata cara penasehat hukum berhubungan dengan tersangka atau terdakwa. Hal penting diatur dalam Pasal 69 KUHAP yang menentukan bahwa penasehat hukum berhak menghubungi tersangka sejak saat ditangkap atau ditahan pada semua tingkat pemeriksaan menurut tata cara yang ditentukan KUHAP, bahwa penasehat hukum berhak menghubungi dan berbicara dengan tersangka pada setiap tingkat pemeriksaan dan setiap waktu untuk kepentingan pembelaan perkaranya". ${ }^{10}$

\section{N. Putusan Mahkamah Konstitusi Nomor 52/PUU-XVI/2018 Tanggal 27 Februari 2019}

Putusan Mahkamah Konstitusi Nomor 52/PUU-XVI/2018 Tanggal 27 Februari 2019, merupakan hasil dari pengujian materil Pasal 16 Undang-

\footnotetext{
${ }^{10}$ Ruslan Renggong, 2016, Hukum Acara Pidana, Cet 2, Prenadamedia Group, Jakarta. Hal, 229.
}

Ibid Hal, 230, 232. 
Undang Nomor 18 Tahun 2003 Tentang Advokat, para pemohon dalam bunyi Petitumnya adalah :

1. Mengabulkan permohonan para pemohon untuk seluruhnya;

2. Menyatakan pasal 16 bertentangan dengan UUD 1945 dan tidak mempunyai hukum mengikat sepanjang tidak dipenuhi syarat bahwa frasa tidak dapat dituntut secara perdata maupun pidana dalam menjalankan tugas profesinya dengan etikad baik tidak dimaknai pengajuan permohonan gugatan perdata ataupun proses pemanggilan dan permintaan keterangan dengan adanya dugaan tindak pidana kepada advokat yang sedang menjalankan tugas profesinya dapat dilakukan setelah mendapatkan keputusan hasil pemeriksaan dari Dewan Kehormatan Profesi Advokat.

3. Memerintahkan amar putusan Mahkamah Konstitusi Yang mengabullkan permohonan para pemohon untuk dimuat dalam berita negara. Atau apabila Mahkamah Konstitusi berpendapat lain, mohon putusan yang seadil-adilnya.

\section{METODE PENELITIAN}

Peneliti akan menguraikan hasil-hasil penelitian yakni kekebalan hukum advokat dan batasannya dalam menjalankan profesinya dengan adanya hak imunitas advokat menurut Pasal 16 Undang-Undang Nomor 18 Tahun 2003 Jo Putusan Mahkamah Konstitusi Nomor 26/PUU-XI/2013 Tanggal 14 Mei 2014, dan jaminan kepastian hukum bagi advokat dalam menjalankan profesinya menurut Pasal 16 Undang-Undang Nomor 18 tahun 2003 Jo Putusan Mahkamah Konstitusi Nomor 26/PUU-XI/2013 Tanggal 14 Mei 2014.

\section{PEMBAHASAN}

\section{A. Kekebalan Hukum dan Batasannya atas Hak Imunitas Advokat Menurut Pasal 16 Undang-Undang Nomor 18 Tahun 2003 Tentang Advokat Jo Putusan Mahkamah Konstitusi Nomor 26/PUU-XI/2013 Tanggal 14 Mei 2014}

Pada dasarnya semua orang sama dimata hukum tidak ada yang kebal hukum akan tetapi, karena profesi advokat merupakan profesi yang mulia maka ia diberikan hak yang istimewa yaitu hak imunitas, hak imunitas merupakan hak atas kekebalan hukum dalam menjalankan profesinya, hak imunitas ini diatur secara khusus dalam Undang-Undang Nomor 18 Tahun 2003 tentang advokat dan kemudian dipertegas lagi 
dalam Putusan Mahkamah Konstusi Nomor 26/PUU-XI/2013 Tanggal 14 Mei 2014 yaitu: Advokat tidak dapat dituntut baik secara perdata maupun pidana dalam menjalankan tugas profesinya dengan iktikad baik untuk kepentingan pembelaan klien didalam maupun diluar sidang pengadilan, selanjutnya dalam penjelasannya adalah yang dimaksud dengan iktikad baik adalah menjalankan tugas profesi demi tegaknya keadilan berdasarkan hukum untuk membela kepentingan kliennya, yang dimaksud dengan sidang pengadilan adalah sidang pengadilan dalam setiap tingkat pengadilan disemua lingkungan peradilan, akan tetapi dari pemahaman penjelasannya ada batasan-batasan atas hak imunitas yang dimiliki advokat, seperti hak imunitas berlaku pada saat menjalankan tugasnya dalam membela kliennya diluar dan didalam sidang pengadilan serta yang paling diutamakan harus dilakukan dengan iktikad baik dan tidak melanggar hukum, hak imunitas ini akan gugur apabila seorang advokat dalam menjalankan profesinya tidak beriktikad baik dan melawan hukum

Istilah Pengecara dan Advokat menurut Pasal 1 angka 1 UndangUndang Nomor 18 Tahun 2003 Tentang Advokat (UU Advokat), Advokat merupakan orang yang berprofesi memberi jasa hukum, baik didalam maupun diluar pengadilan yang memenuhhi persyaratan berdasarkan ketentuan UU Advokat, pengecara merupakan sebutan lain yang banyak digunakan bagi profesi advokat. Kesamaan antara keduanya dapat disimak dalam definisi advokat yang tercantum dalam Kode Etik Advokat Indonesia (KEAI), Pasal 1 huruf a KEAI yang berbunyi: Advokat adalah orang yang berpraktek memberi jasa hukum, baik didalam maupun diluar pengadilan yang memenuhhi persyaratan berdasarkan Undang-Undang yang berlaku, baik sebagai advokat, pengecara, penasehat hukum, pengecara praktek ataupun sebagai konsultan hukum, dengan demikian, jelas bahwa pengecara merupakan suatu profesi yang juga tunduk pada UU Advokat dan KEAI. Guna menyeragamkan peristilahan dengan UU Advokat, maka akan menggunakan istilah advokat dalam jawaban ini. Advokat bebas dalam menjalankan tugas profesinya untuk membela perkara yang menjadi tanggung jawabnya dengan tetap berpegang pada kode etik profesi advokat dan peraturan perundang-undangan. Ketentuan ini mengatur mengenai hak imunitas atau kekebalan advokat dalam menjalankan tugas profesinya untuk kepentingan kliennya diluarsidang pengadilan dan dalam mendampingi kliennya, dalam Pasal 16 UU Advokat juga menyebutkan: Advokat tidak dapat dituntut baik secara perdata maupun pidana dalam menjalankan tugas profesinya dengan iktikad baik untuk kepentingan pembelaan klien dalam sidang pengadilan.

"Mahkamah konstitusi, melalui putusannya Putusan Mahkamah Konstitusi Nomor 26/PUU-XI/2013 Tanggal 14 Mei 2014, memberi 
catatan bahwa Pasal 16 UU Advokat bertentangan dengan UUD 1945 dan tidak mempunyai kekuatan hukum mengikat sepanjang tidak dimaknai bahwa advokat tidak dapat dituntut baik secara perdata maupun pidana dalam mennjalankan tugas profesinya dengan iktikad baik untuk kepentingan pembelaan klien didalam maupun diluar sidang pengadilan. Lebih lanjut, yang dimaksud dengan iktikad baik adalah menjalankan tugas profesinya demi tegaknya keadilan berdasakan hukum untuk membela kepentingan kliennya. Sementara sidang pengadilan adalah sidang pengadilan dalam setiap tingkat pengadilan. Mengutip artikel yang berjudul Benarkah Advokat itu Kebal Hukum, Luhut M.P. Pangribuan, menjelaskan bahwa jika ada dugaan tindak pidana yang dilakukan oleh seorang advokat maka hak imunitas atau kekabalan hukum advokat itu tidak berlaku, misalnya dengan cara-cara melanggar hukum, dengan demikian kekebalan hukum bagi advokat tidak berlaku dalam setuasi sebagaimana yang diatur dalam UU Advokat dan KEAI.

Mahkamah Konstitusi menegaskan, meskipun hak imunitas advokat dijamin dan dilindungi dalam undang-undang advokat, namun tidak serta-merta membuat advokat menjadi kebal terhadap hukum, ini karena hak imunitas tersebut digantungkan kepada apakah profesinya dilakukan berdasarkan iktikad baik atau tidak, menurut Hakim konstitusi, Menahan Sitompul di Gedung Makamah Konstitusi.

Ketua Mahkama Konsitusi, Menahan, memaparkan hal tersebut ketika membacakan pertimbangan Mahkamah Konstitusi dalam sidang pembacaan putusan perkara pengujian UU Advokat, dalam penjelasan Pasal UU Advokat dinyatakan bahwa yang dimaksud dengan iktikad baik adalah menjalankan tugas profesinya demi tegaknya keadilan berdasarkan hukum untuk membela kepentingan kliennya. Maka dengan demikian pengertian ikikad baik yang diberikan dalam penjelasan pasal 16 UU Advokat mensaratkan dalam membela kepentingan kliennya selanjutnya advokat harus tetap berdasarkan aturan hukum. Selanjutnya dalam pertimbangan Putusan Mahkamh Konstitusi Nomor 7/PUU-XVI/2018 Tanggal 28 Februari 2018, berbunyi bahwa kata kunci dari rumusan hak imunitas dalam ketentuan tersebut bukan terletak pada "kepentingan pembelaan klien", melainkan pada "iktikad baik". Artinya hak imunitas tersebut dengan sendirinya gugur bila unsur iktikad baik dimaksud tidak dipenuhi. Kebebasan atau hak imunitas profesi advokat saat melaksanakan tugas pembelaan hukum kepada kliennya harus didasarkan kepada iktikad baik, yakni berpegang pada kode etik dan peraturan perundang-undangan. Atas dasar pertimbangan tersebut, 
Mahkamah Konstitusi dalam putusannya menyatakan menolak permohonan pemohon untuk seluruhnya". ${ }^{11}$

Advokat mempunyai hak imunitas atau kondisi ketika seseorang advokat tidak bisa dituntut ketika menjalankan tugas yang dijamin oleh undang-undang, namun bukan berarti advokat kebal hukum.

Meskipun telah ada peraturan perundang-undangan yang menjamin hak imunitas advokat, namun apabila melihat yang terjadi saat ini, banyak sekali advokat yang dilaporkan kepihak yang berwajid dan dipidana atas perbuatan atau kesalahan penyalahgunaan wewenangnya dalam menjalankan tugas profesinya.

Berdasarkan kasus tersebut hukuman yang palng tinggi untk advokat yang terbukti bersalah adalah Haposan Hutagalung (divonis 12 tahun penjara), adapun sebagian dari advokat yang terkena kasus tersebut adalah sebagai berikut:

Pertama atas nama Lambertus Palang Ama, pada Tahun 2010, Ia terlibat dalam kasus Gayus Halomoan Tambunan dengan memberikan keterangan tidak benar dan merekayasa asal-usul uang Rp 28 miliar milik Gayus. Atas perbuatannya, Ia dijerat dengan Pasal 22 dan Pasal 28 UU Tipikor dan divonis Pengadilan Negri Jakarta Selatan 3 tahun penjara ditambah denda Rp 150 juta. Ia terbukti membantu merekayasa asal-usul uang senilai Rp 28 miliar milik Gayus tersebut.

Kedua atas nama Susi Tur Andayani, Ia merupakan pengecara Amir Hamzah dan Kasmin, salah satu pasangan calon Bupati dan Wakil Bupati Lebak, waktu kasus sedang bergulir, untuk memenangka gugatan sengketa Pilkada, Susi yang dikenal dengan Akhil Mochtar yang merupakan Ketua Mahkamah Konstitusi (MK), saat itu, mengambil jalan pintas memberikan uang senilai Rp 1 Miliar ke Akhil, untuk memenangkan Gugatan perkara sengketa Pilkada Kabupaten Lampung Selatan. Pemberian uang ditujukan supaya Akhil memnangkan keberatan yang diajukan oleh pasangan Amir Hamzah dan Kasmin terhadap Pasangan calon Iti Octavia Jayabaya dan Ade Sumardi. Selain itu juga untuk memenangkan pasangan pilkada Kabupaten Lampung Selatan terpilih Rycko Menoza dan Eky Seyanto. Atas perbuatan yang dilakukan Susi dijatuhkan vonis hukuman oleh Majelis Hakim Pengadilan Tidak Pidana Korupsi (Tipikor), selama 5 tahun penjara dan denda Rp 150 Juta Subsidar 3 bulan kurungan.

Ketiga atas nama Fredrich Yunadi, KPK menetapkan Ia sebagai tersangka kasus dugaan menghalangi dan merintang penyidikan kasus eKTP dengan tersangka Setya Novanto pada 10 Januari 2018, karena tak memenuhi panggilan pemeriksaan, feredrich ditangkap dan ditahan KPK

\footnotetext{
${ }^{11}$ https://nasional.kompas.com/read/2019/02/28/16224231/mk-advokat-tidak-kebalhukum Diakses Hari Saptu 4 april 2020, Pukul 22:16 Wita.
} 
pada sabtu 13 Januari 2018. kasus ini sampai pada tingkat kasasi, Majelis Hakim Kasasi Mahkamh Agung (MA) memperberat hukuman vonis terhadap Fredrich Yunadi menjadi 7,5 tahun penjara dan denda Rp 500 juta, subsidair 8 bulan kurungan. Ia merupakan mantan kuasa hukum ketua DPR RI (Setya Novanto) dalam perkara korupsi e-KTP. sebelumnya ia divonis dan diperberat 6 bulan penjara karena adanya kesengajaan dengan tujuan menghalangi dan merintang penyidikan KPK (opzet als oogmerk). itu sesui permintaan Jaksa Penuntut Umum. Sebelumnya juga Pengdilan Tinggi Jakarta menjatukan vonis 7 tahun penjara ditambah denda Rp 500 juta, subsidair 5 bulan kurungan kepada Fredrich. Ia terbukti menghalangi dan merintangi pemeriksaan Setya Novanto dikomisi pemberantasan koupsi.

Berdasarkan kasus ini dan masih banyak lagi contoh kasus-kasus yang lainya yang melibatkan Pengecara atau Advokat dengan begitu bahwa berdasarkan Asas Legalitas dan persamaan dihadapan hukum dalam hal ini dapat dinyatakan bahwa pada dasarnya Advokat tidak Kebal hukum tetapi Advokat memiliki kekebalan yaitu Hak Imunitas sesuai yang tertuang dalam Pasal 16 Undang-Undang Nomor 18 Tahun 2003 Tentang Advokat yang berbunyi: Advokat tidak dapat dituntut baik secara perdata maupun pidana dalam menjalankan tugas profesinya dengan iktikad baik untuk kepentingan pembelaan klien dalam sidang pengadilan, kemudian diperkuat melalui Putusan Mahkama konstitusi Nomor 26/PUU-XI/2013 Tanggal 14 Mei 2014, dalam Amar putusannya mengabulkan pengujian Pasal 16 Undang-Undang Nomor 18 Tahun 2003 Tentang Advokat yang berbunyi: Advokat tidak dapat dituntut baik secara perdata maupun pidana dalam menjalankan tugas profesinya dengan iktikad baik untuk kepentingan pembelaan klien didalam maupun diluar sidang pengadilan.

Hak Imunitas atau kekebalan hukum yang dimiliki advokat berdasarkan penjelasan dalam Pasal 16 Undang-Undang Nomor 18 Tahun 2003, yang dimaksud dengan iktikad baik adalah menjalankan tugas profesi demi tegaknya keadilan berdasarkan hukum untuk membela kepentingan kliennya kemudian yang dimaksud dengan sidang pengadilan adalah sidang pengadilan dalam setiap tingkat pengadilan disemua lingkungan peradilan, jadi dapat disimpulkan Advokat akan kebal hukum dengan adanya hak imunitas apabila Ia menjalankan tugas profesinya dengan etikad baik dan tidak melanggar peraturan perundang-undangan serta kode etik advokat, sebaliknya kekebalan atau hak imunitas akan batal apabila advokat dalam menjalankan profesinya tidak beriktikad baik dan melanggar peraturan perundang-undangan.serta kode etik advokat. 


\section{B. Perlindungan Hukum Advokat Dalam Menjalankan Tugas Profesinyan menurut Pasal 16 Undang-Undang Nomor 18 Tahun 2003 Tentang Advokat Jo Putusan Mahkamah Konstitusi Nomor 26/PUU-XI/2013 Tanggal 14 Mei 2014}

Perlindungan hukum merupakan hak asasi setiap orang yang dijamin oleh kontitusi, begitu pula dengan seseorang yang berprofesi sebagai advokat, dalam menjalankan profesinya tentu harus dijamin oleh hukum atas perlindungan hukum bagi advokat agar tidak mudah dirampas hakhaknya dalam menjalankan profesinya sebagaimana didalam pasal 16 Undang-Undang Nomor 18 Tahun 2003 Tentang Advokat dan dalam Putusan Mahkamah Konstitusi Nomor 26/PUU-XI/2013 Tanggal 14 Mei 2014 menegaskan perlindungan atas hak advokat yaitu Advokat tidak dapat dituntut baik secara perdata maupun pidana dalam menjalankan tugas profesinya dengan iktikad baik untuk kepentingan pembelaan klien didalam maupun diluar sidang pengadilan, yang dimaksud dengan sidang pengadilan adalah sidang pengadilan dalam setiap tingkat pengadilan disemua lingkungan peradilan,

Pengakuan atas hak dan peran advokat sebagai bagian dari sistem hukum dan peradilan harus dihormati semua pihak dan aparat penegak hukum lainnya, terutama dalam kesetaraan dalammenjalankan fungsi dan tugasnya, bersumber pada Undang-Undang Nomor 18 Tahun 2003. Dengan adanya payung hukum bagi profesi advokat dalam UndangUndang Nomor 18 Tahun 2003 Tentang Advokat, maka hak advokat yang dikatakan paling sentral adalah Hak Imunitas (Immuniteit) atau kekebalan untuk tidak dapat dituntut baik secara perdata maupun pidana dalam menjalankan tugas profesinya dengan itikad baik dalam sidang pengadilan,

Undang-Undang Nomor 8 Tahun 1981 Tentang Kitab UndangUndang Hukum Acara Pidana.

Pada dasarnya terkait peraturan-peraturan maupun perundangundangan yang mengatur perlindungan hukum atau hak-hak yang melekat pada advokat hingga adanya Putusan Mahkamah Konstitusi Nomor 26/PUU-XI/2013 Tanggal 14 Mei 2014, terkait pengujian Pasal 16 Undang-Undang Nomor 18 Tahun 2003 Tentang Advokat sesudahnya masih ada upaya perlusan lagi terhadap hak-hak advokat dalam menjalankan tugas profesinya yaitu terkait pengujian materil Pasal $21 \mathrm{UU}$ TIPIKOR sehingga adanya Putusan Mahkamah Konstitusi Nomor 7/PUUXVI/2018 Tanggal 28 Februari 2018 dan pengujian materil Pasal 16 Undang-Undang Nomor 18 Tahun 2003 Tentang Advokat sehingga adanya Putusan Mahkamah Konstitusi Nomor 52/PUU-XVI/2018 Tanggal 27 Februari 2019, namun dari kedua upaya yang dilakukan ditolak sepenuhnya oleh Mahkamah Konstitusi. 


\section{A. Kesimpulan}

\section{PENUTUP}

1. Pada dasarnya Advokat tidak kebal hukum sesuai dengan Asas Persamaan Dihadapan Hukum, tetapi advokat memliki kekebalan yaitu hak imunitas, hak imunitas ini tertuang dalam Pasal 16 UndangUndang Nomor 18 tahun 2003 Tentang Advokat dan Putusan Mahkamah Konstitusi Nomor 26/PUU-XI/2013 Tanggal 14 Mei 2014, "Advokat tidak dapat dituntut baik secara perdata ataupun pidana dalam menjalakan tugas profesinya dengan itikad baik untuk pembelaan klien di dalam maupun di luar pengadilan".

2. Advokat dalam menjalankan tugasnya profesinya diberikan perlindungan hukum yaitu dalam UU Advokat, UU Bantuan Hukum, Putusan MK serta dalam KEAI, namun terkadang masih banyak seorang advokat yang terseret ke Pengadilan karena kehilangan hak imunitas atas kelalaian ataupun kesengajaan penyalahgunakan wewenangnya, yang seharusnya dia dapat. Pada dasarnya advokat memiliki hak imunitas sesuai Undang-Undang Nomor 18 tahun 2003 Tentang Advokat Pasal 16, Advokat tidak dapat dituntut baik secara perdata ataupun pidana dalam menjalakan tugas profesinya dengan itikad baik untuk pembelaan klien di dalam maupun di luar pengadilan. Secara garis besar, advokat yang tidak memiliki itikad baik dalam menjalakan tugas profesinya adalah advokat yang bisa terseret ke pengadilan, atau dengan kata lain kehilangan hak imunitas itu sendiri.

\section{B. Saran}

1. Menjelaskan secara detail Undang-Undang Nomor 18 Tahun 2003 Tentang Advokat, terutama mengenai Hak Imunitas atau kekebalan hukum yang dimiliki Advokat, agar tidak terjadi multi-tafsir.

2. Seharusnya perlindungan hukum terhadap advokat dalam menjalankan peran, tugas profesinya lebih dipertegas lagi dan bagi advokat sendiri harus mengetahui dan menyadari terkait ha-hak dan kewajibanya dalam menjalankan tugas profesinya agar tidak terjerumus dalam penyalahgunaan tugas dan wewenangnya. 


\section{DAFTAR PUSTAKA}

\section{A. Buku Bacaan Hukum}

Abdul Munif, 2013, Pengantar Hukum Indonesi, Cet 2, Penerbit Cakrawala Media, Yogyakarta.

Andika Wijaya dan Wida Peace Ananta, 2019, Ujian Profesi Advokat, Cet. IV, Penerbit PT Grasindo, Jakarta.

Daniel s. Lev, 2001, Advokat Indonesia Mencari Legitimasi, Cet. III, Penerbit Pusat Studi Hukum dan kebijakan indonesi, Jakarta.

H Muladi, 2009, Hak Asasi Manusia, Cet 3,Penerbit PT Refika Aditama, Jakarta.

Ruslan Renggong, 2016, Hukum Acara Pidana, Cet 2, Prenadamedia Group, Jakarta.

Suhrawardi K. Lubis, 2017, Etika Profesi Hukum, Cet 10, Penerbit Sinar Grafika, Jakarta.

V. Harlen Sinaga, 2011, Dasar-dasar Profesi Adfokat, Cet I, Penerbit Erlangga, Jakarta.

V.Yahman dan Nurtin Tarigan, 2019, Peran Advokad Dalam Sistem Hukum Nasional, Cet. I, Penerbit Prenadamedia Group, Jakarta.

\section{B. Peraturan Perundang-undangan}

Undang-Undang Dasar 1945

Undang-Undang Nomor 8 Tahun 1981 Tentang Kitab Undang-Undang Hukum Acara Pidana, (KUHAP).

Undang-Undang Nomor 39 Tahun 1999 Tentanng Hak Asasi Manusia.

Undang-Undang Nomor 18 Tahun 2003 Tentang Advokat.

Undang-Undang Nomor 16 Tahun 2011 Tentang Bantuan Hukum.

Kode Etik Advokat Indonesia.

Keputusan Mahkamah Konstitusi Nomor 26/PUU-XI/2013 Tanggal 14 Mei 2014.

Keputusan Mahkamah Konstitusi Nomor 52/PUU-XVI/2018 Tanggal 27 Februari 2019 


\section{Sumber Lainnya}

https://www.google.com/search?client=firefox-b$\mathrm{d} \& \mathrm{q}=$ skripsi+hak+imunitas+adfokat.

https://www.jawapos.com/nasional/hukum-kriminal/14/01/2018/icwselain-fredrich-sudah-ada-22-advokat-yang-terjerat-kasus-hukum/

https://www.hukumonline.com/berita/baca/lt540d7c056fc44/hak-imunitasdan-asas-persamaan-kedudukan-di-hadapan-hukum-dalam-uumd3-broleh--prof-mardjono-reksodiputro--sh--ma

https://id.wikipedia.org/wiki/Hak_imunitas/

https://www.hukumonline.com/berita/baca/lt53734eff625ec/akhirnya-advokat-dapat-perlindungan-di-luar-sidang

https://nasional.kompas.com/read/2019/02/28/16224231/mk-advokattidak-kebal-hukum.

https://www.google.com/search?safe=strict\&client=firefox $-b-$ $\mathrm{d} \&$ sxsrf=ALeKk02HH82RIubwacNq3vjPYlhnqAdAw\%3A1586010784058\&ei=oJqIXpKZA4Ce4EPicmU4AM\&q=skripsi+perlindungan+hukum+hak+imunitas+ad vokatY3SggIGBIEMTItM1COxAZYjsQGYIfYBmgAcAJ4AIAB mwGIAZsBkgEDMC4xmAEAoAEBqgEHZ3dzLXdpeg\&sclient= psy-ab. 